\title{
TAFSIR KOMPREHENSIF KARYA CLIFFORD GEERTZ: ABANGAN, SANTRI, DAN PRIYAYI DALAM MASYARAKAT JAWA
}

\section{Miftakhur Ridlo \\ Institut Agama Islam Uluwiyah Mojokerto \\ rheydlo@yahoo.co.id}

\begin{abstract}
Geertz has made many contributions related to the typology of Javanese society, especially in matters of religious typology. In line with that, a lot of controversy and criticism were addressed to him. This is due to the inequality of ideas conveyed, especially globalization or the universality of religious concepts in Javanese society which is represented by only one, in Modjokuto village. As a result, many new studies have spawned almost the same discussion, namely the intersection between Islam and local culture in other areas such as : Yogyakarta, Buton, Lombok and others. It is interesting when discussing the concepts of syncretism, acculturation, Islamization, and indigenization. This is due to the uniqueness of the form of Islamic meeting or processes in various regions which are relatively different. The reason is difference local wisdom and traditions that have been rooted in the community. The difference in local wisdom may be a motivation for Islamic scientists' to further explore some of the unique traditions that may not have been raised in academic circles.
\end{abstract}

Keywords: interpretations, Clifford Geertz

https:/ / ejournal.unzah.ac.id/index.php/humanistika 


\title{
Miftakhur Ridlo
}

\begin{abstract}
Abstrak
Geertz telah memberikan banyak sumbangsih terkait dengan tipologi masyarakat Jawa, khususnya dalam masalah tipologi keberagamaan. Sejalan dengan itu, banyak kontrovesi dan kritik yang dialamatkan kepadanya. Hal ini dikarenakan adanya ketimpangan gagasan yang disampaikan, terutama globalisasi atau universalitas konsep keagamaan dalam masyarakat Jawa yang terwakili hanya satu, di desa Mojokuto. Sehingga banyak melahirkan penelitian baru yang pembahasannnya nyaris sama, yaitu persinggungan antara Islam dan budaya lokal di wilayah lain seperti : Yogyakarta, Buton, Lombok dan lainlain. Memang menarik ketika membahas tentang konsep sinkretisme, akulturasi, islamisasi,dan pribumisasi. Hal ini disebabkan keunikan bentuk pertemuan atau proses keislaman di berbagai daerah yang relatife berbeda. Penyebabnya adalah kearifan lokal yang berbeda dan tradisi yang sudah mengakar di kalangan masyarakat. Perbedaan kearifan lokal tersebut kiranya menjadi motivasi bagi para ilmuwan Islam, untuk lebih menggali beberapa keunikan tradisi yang mungkin belum dimunculkan di kalangan akademisi.
\end{abstract}

Humanistika: Vol. 7 No. 22021. 


\section{Pendahuluan}

Karya berjudul asli The Religion of Java ditulis oleh Clifford Geertz, guru besar University of Chicago yang melakukan pekerjaan lapangan di Mojokuto dari bulan Mei 1953 sampai bulan September 1954. Studi tersebut telah diajukan sebagai disertasi doktoral, dengan pendahuluan dan kongklusi yang berlainan, kepada Departemen Hubungan Sosial di Harvard University dalam musim semi tahun $1956 .{ }^{1}$ Karya ini mengambarkan secara detail dan spesifik tentang agama dan kebudayaan masyarakat Jawa. Walaupun tidak menutup kemungkinan bahwa ini hanyalah sebuah penelitian di satu daerah saja, yang kemudian difahami sebagai globalitas terhadap keberagamaan khususnya di Jawa.

Karya ini disandingkan dengan Islam Observed : Religion Development in Maroccoand Indonesia (Tahun 1968) ${ }^{2}$ yang menjelaskan tradisi sosiologis antropologis Islam dan masyarakat muslim. Dalam Islam Observed, Geertz membandingkan kehidupan religi-sosial masyarakat muslim Maroko dengan masyarakat muslim Jawa. Dalam pandangan pertama, Islam tampil lebih skripturalistik, sedangkan dalam masyarakat kedua, Islam dipandang lebih akomodatif dan nyaris bersifat sinkretik. Gambaran inilah ada anggapan bahwa Islam Jawa atau Islam Indonesia secara keseluruhan adalah Islam peripheral atau Islam yang tidak murni, vis-à-vis Islam Timur

${ }^{1}$ Cliffort Geertz, The Religion of Java, (Glencoe London : The Free Press, 1960). Diterjemahkan dalam bahasa Indonesia dengan judul: Abangan, Santri, Priyayi dalam Masyarakat Jawa (Jakarta: Dunia Pustaka Jaya, 1981), 251

${ }^{2}$ Geertz menyatakan bahwa Islam yang masuk ke Indonesia secara sistematis baru pada abad ke-14, berpapasan dengan suatu kebudayaan besar yang telah menciptakan suatu sistem politik, nilai estetika dan kehidupan keagamaan yang sangat maju. Yang dikembangkan oleh kerajaan Hindu-Budha di Jawa, dan telah sanggup menanamkan nilai yang mengakar pada kehidupan masyarakat Indonesia. Wahid Zaini, Dunia Pemikiran Kaum Santri, (Yogyakarta : LKPSM NU, 1995), v-vi

Humanistika: Vol. 7 No. 22021. 


\section{Miftakhur Ridlo}

Tengah yang dipandang merupakan Islam murni dan Islam pusat. ${ }^{3}$ Melalui perbandingan tersebut, terkesan masyarakat muslim yang terikat dalam keimanan dan keislaman yang sama, dalam pengejawantahan mereka terlihat jelas adanya perbedaan tertentu terutama bentuk kebudayaannya. Karena itu, hasil kajian tentang Islam memunculkan Islam sebagai kebudayaan, atau Islam as a culture. ${ }^{4}$

\section{Karya Clifford Geertz}

Clifford Geertz merupakan antropolog Amerika yang memberikan sebuah sintesa atau tipologi terhadap masyarakat Jawa. Menurutnya penggolongan penduduk menurut kepercayaan keagamaan, preferensi etnis dan ideologi politik menghasilkan tiga tipe utama kebudayaan yang mencerminkan organisasi moral kebudayaan Jawa sebagaimana dicerminkan di Mojokuto adalah abangan, santri dan priyayi. Ide umum ini berkenaan dengan tingkah laku petani, buruh, pekerja tangan, pedagang dan pegawai Jawa dalam semua area kehidupan. Tiga inti struktur sosial yang dominan di Jawa adalah : pasar, desa dan birokrasi pemerintahan. ${ }^{5}$

Karyanya juga menciptakan sebuah perbandingan Islam santri dengan abangan, abangan difahami orang yang acuh terhadap doktrin, terpesona oleh detail keupacaraan. Santri diartikan sebagai orang yang perhatian terhadap doktrin Islam terutama penafsiran moral dan sosialnya. Dalam masalah organisasi sosial, abangan melakukan upacara (slametan) berlangsung di rumah tangga : suami, istri dan anaknya. Sedangkan santri, rasa perkauman adalah umat Islam seluruhnya. ${ }^{6}$

\footnotetext{
${ }^{3}$ Azyumardi Azra (Kata Pengantar) dalam buku Bambang Pranowo, Memahami Islam Jawa, terj : Ridwan Muzir, (Jakarta : Pustaka Alvabet dan LaKIP, 2011), xii

${ }^{4}$ Bambang Pranowo, Islam Faktual : Antara Tradisi dan Relasi Kuasa, (Yogyakarta : Adicita Karya Nusa, 1998), vii

${ }^{5}$ Geertz .., 6

${ }^{6}$ Ibid .., $172-176$
}

Humanistika: Vol. 7 No. 22021. 
Abangan mewakili suatu titik berat pada aspek animistik dari sinkretisme Jawa dalam berbagai hal, dan secara luas dihubungkan dengan elemen petani. Santri, mewakili suatu titik pada aspek Islam dan umumya dihubungkan dengan elemen pedagang (dan kepada elemen tertentu di kalangan petani juga). Priyayi menekankan aspek Hindu-Budha dan dihubungkan dengan elemen birokratik. ${ }^{7}$ Kebanyakan kaum priyayi mulanya berasal dari Mataram, sebagian besarnya abangan, tetapi sebagian berasal dari wilayah dataran Brantas dan Kediri, dan penduduk santrinya berasal dari pesisir utara.

Sistem keagamaan desa lazimnya terdiri dari suatu integrasi yang berimbang antara unsur animisme, Hindu-Budha dan Islam, sehingga disebut sinkretisme. Tradisi keagamaan abangan, yang terutama sekali terdiri dari pesta keupacaran yang disebut slametan. Slametan adalah wadah mempertemukan berbagai aspek kehidupan sosial dan pengalaman perseorangan, dengan suatu cara yang memperkecil ketidakpastian, ketegangan dan konflik. Kepercayaan yang kompleks dan rumit terhadap makhluk halus dan seluruh rangkaian teori dan praktek pengobatan, sihir, dan magik. ${ }^{8}$

Geertz, menyimpulkan adanya konflik antar agama dan sosial, yaitu : ketegangan jelas antara kaum santri dan dua kelompok lainnya, tetapi ketegangan yang berarti antara priyayi dan abangan juga. Sejak masa pertikaian antara kerajaan mataram di Jawa Tengah dan kerajaan pelabuhan pantai utara, paling tidak yaitu sejak abad keenam belas dan tujuh belas, priyayi dan santri tidak sepakat dalam banyak hal. Kebencian petani terhadap aristokrasi yang memerintah yang kurang lebih ekspoitasi dan kelas pedagang santri yang cerdas yang berpusat di kota.

${ }^{7}$ Ibid ..., 8
${ }^{8}$ Ibid .., 17

Humanistika: Vol. 7 No. 22021. 


\section{Miftakhur Ridlo}

Konflik ideologi, yaitu : Moralitas kaum santri lebih suci dari pada kaum abangan, tetapi di sisi lain sepanjang pusat pada ideologi, universalisme dan salvasionisme santri juga menimbulkan serangan kaum abangan yang pragmatis dan relativistis. Dalam serangan priyayi, kritik terhadap kemunafikan santri dan intoleransi mereka sering digabungkan dengan perbedaan teoritis mengenai pola kepercayaan. Dari pihak kaum santri, menuduh kaum abangan sebagai penyembah berhala dan menuduh priyayi tidak bisa membedakan dirinya dengan Tuhan (dosa takabur yang berat sekali) dan mereka mempunyai tendensi yang jelas untuk menganggap setiap orang di luar kelompoknya sebagai komunitas.

Konflik kelas, yaitu Ketegangan priyayi abangan terlihat paling jelas dalam hubungannya dengan persoalan status. Priyayi sering menuduh orang desa tahu tempatnya yang layak dan karenanya mengganggu keseimbangan organik masyarakat, mempersalahkan mereka sebagai berlamunan besar, dan gagal meniru gaya hidup priyayi. Konflik politik, yaitu : faktor psikologis, agama dan integrasi sosial, nasionalisme dan proyeksi tentang kebudayaan bersama yang baru, tipe campuran dan kelompok marjinal, faktor struktur sosial, toleransi dan integrasi sosial yang pluralistik. ${ }^{9}$

\section{Kritik Terhadap Konsepsi Geertz}

Islam masuk ke wilayah kepulauan Indonesia tidak disebarkan oleh bangsa Gujarat dan bangsa Benggali, akan tetapi orang Arab. ${ }^{10}$ Tidak diragukan mereka mempunyai peran dalam proses pengislaman. Mereka

\footnotetext{
${ }^{9}$ Geertz .., 476

10 Dapat dikatakan bahwa para navigator dan pedagang Arablah yang telah memperkenalkan Islam di Nusantara, pertama di Aceh, Palembang dan Jawa. Sejumlah orang Arab telah menetap di pelabuhan penting Nusantara dan beberapa diantaranya, bahkan mempunyai pengaruh yang mencolok atas masa depan politik golongan pribumi. Van den Berg, Hadramaut dan Koloni Arab Di Nusantara, (Jakarta : INIS, 1989), 67
}

Humanistika: Vol. 7 No. 22021. 
berperan ganda sebagai pedagang dan sebagai mubalig. Mudahnya Islam diterima karena Islam tidak membedakan antara rasa atau antara kelas, tetapi sebaliknya membantu menggalang persatuan sosial. Ditambah, faktor politik karena para penguasa masuk Islam sehingga rakyatnya banyak yang mengikutinya. Hal yang tidak dapat dikesampingkan adalah proganda Kristen, ${ }^{11}$ sehingga proses pengislaman serta perluasan kekuasaan Islam semakin mudah.

Dalam pandangan sejarawan, Islamisasi ${ }^{12}$ masyarakat Jawa adalah transisi budaya yang terus berlanjut. Setelah mungkin seribuan tahun menerima Hindu, orang Jawa mulai menerima Islam. Tetapi Islamisasi Jawa tidaklah berjalan dengan linier, sejarah Islamisasi sangat kompleks, penuh dengan kejutan sepanjang 600 tahun sejak Islam pertama kali datang, dan itu belum selesai. Dalam kerangka tersebut, sejak Islam datang ke Jawa pada abad ke-14, terlihat adanya tensi serta konflik antara Islam dengan kepercayaan dan budaya lokal Jawa. Setelah berjalannya waktu,

${ }^{11}$ Zaini Muchtarom, Santri dan Abangan Di Jawa, (Jakarta : INIS, 1988), 16-18

${ }^{12}$ Format Islamisasi menyerupai sekte revolusionis dengan bukti historis di Aceh, ketika sufisme berkadar rendah bertemu budaya lokal belum mapan. Sebaliknya ketika sufisme berkadar tinggi bertemu budaya lokal yang minim, muncullah pribumisasi. Namun ketika sufisme rendah bertemu budaya lokal yang surut yang muncul adalah negosiasi. Ketika sufisme berkadar tinggi dan juga budaya lokal, maka akan melahirkan format konflik menyerupai sekte reformis. Abdul Munir Mulkham, Islam Sejati : Kiai Dahlan dan Petani Muhammadiyah, (Jakarta : Serambi, 2003), 35. Kecenderungan reformis adalah : 1) mempertahankan sistem dari abad permulaan Islam yang dibersihkan dari bid'ah, 2) membangun kembali ke agama Islam yang didasarkan atas ajaran yang benar disesuaikan dengan masa kini dalam hal agama, kesusilaan dan kemasyarakatan, 3) berpegang teguh terhadap dasar Islam dan tidak menutup pintu pandangan yang datang dari Barat. Pijper, Beberapa Studi Tentang Sejarah Islam Di Indonesia 1900-1950, terj : Tudjimah dan Yessy Augudin, (Jakarta : UI Press, 1985), 164

Humanistika: Vol. 7 No. 22021. 


\section{Miftakhur Ridlo}

orang Jawa melihat diri mereka secara alamiah memiliki identitas pokok yang didefinisikan Islam. ${ }^{13}$

Sebelum Islam datang, Jawa telah memiliki ajaran kearifan yang mapan, kehadiran Islam tidak menghapus kearifan itu, malah justru menempurnakannya. Orang Jawa sangat terbuka terhadap keyakinan dari semua agama terutama Islam. Namun, mereka tidak mau ketika diArabkan sebagaimana mereka juga menolak mati-matian saat hendak diBelandakan atau di-Inggriskan. ${ }^{14}$ Belajar dari kearifan yang tersirat dan tersurat dalam kalangan Jawa bukanlah tujuan, melainkan vitamin dan suplemen penambah energi untuk membangkitkan semangat keagamaan yang mulai mengendor.

Menurut Parsudi, agama Jawa bukanlah agama pemujaan leluhur, tetapi berintikan pada prinsip utama yang dinamakan sangkan paraning dumadi (dari mana manusia berasal, apa dan siapa dia dimasa kini, dan kemana arah tujuan hidup yang dijalani dan ditujunya). Prinsip ini menyangkut dua hal, yaitu : konsep mengenai eksistensi dan tempat manusia di alam semesta beserta isinya, dan berbagai kegiatan yang berkaitan dengan lingkaran hidup. Hakikat tindakan keagamaan yang berwujud dalam bentuk upacara adalah untuk mencapai tingkat selamat atau kesejahteraan yaitu suatu keadaan ekuilibrium unsur-unsur yang ada dalam isi suatu wadah tertentu. ${ }^{15}$

Menurut Bachtiar, penggunaan istilah abangan, santri, dan priyayi untuk mengklasifikasikan masyarakat Jawa dalam golongan agama tidaklah tepat. Karena ketiga golongan yang disebutkan tadi bersumber pada satu sistem klasifikasi yang tidak sama (abangan dan santri adalah pengolongan yang dibuat menurut tingkat ketaatan mereka menjalankan

\footnotetext{
${ }^{13}$ Bambang, Memahami Islam Jawa .., xv

${ }^{14}$ Abdurrahman El Ashiy, Makrifat Jawa untuk semua, (Jakarta : Serambi, 2011), 2

${ }^{15}$ Pursudi Suparlan, "Kata Pengantar," dalam Cliffort Geertz, Abangan, vii-xiii. Humanistika: Vol. 7 No. 22021.
} 
ibadah agama Islam, sedangkan priyayi adalah golongan sosial). Terlebih, istilah abangan mempunyai makna dejoregatife, dan isinya bersifat merendahkan derajat yang biasanya digunakan mereka yang taat beragama Islam untuk menamakan mereka yang tidak atau kurang taat. ${ }^{16}$

Nakamura antropolog Jepang, dalam buku Bambang Pranowo berpendapat bahwa konsep sabar, ikhlas, slamet yang diperkenalkan Geertz sebagai nilai utama dalam pandangan masyarakat tradisional Jawa, sebenarnya bersumber dari ajaran Islam. Nakamura menunjukkan istilah yang menjadi kunci tata nilai masyarakat Jawa ini sebenarnya berasal dari bahasa Arab dan bersumber pada ajaran Islam, dan pemakaian istilah tersebut dalam bahasa Jawa kontemporer sangat serasi dengan pengertian religiusnya asli. Istilah sabar berasala dari bahasa Arab shabr dalam alQuran (al-Qur'an : 23, 111 : 28, 54). Istilah ikhlas berasal dari dari bahasa Arab pula yang berarti "berbakti kepada Tuhan". Sedangkan slamet berasala dari bahasa Arab salam yang berarti damai atau salam : baik, selamat. ${ }^{17}$

Pandangan Geertz tersebut, juga di kritik oleh sejarawan Marshall Hodgson, bahwa keungulan kajian Geertz tentang masyarakat muslim Jawa ditadai kesalahan sistematika besar. Ketika Geertz mengedintifikasi kaum santri berdasarkan kerangka yang diberikan kaum skripturalis, dan pada saat yang sama mengelompokkan kaum muslim lainya ke dalam kelompok abangan. Kelompok terakhir ini secara implisit dia disebut sebagai lebih menganut tradisi Hindu daripada Islam. Bertahannya kelompok abangan terutama karena Islam di Indonesia telah lama terputus dengan pusat Islam di Timur Tengah seperti Mekah, Madinah dan bahkan Kairo. Argumen ini jelas keliru, karena sejak awal perkembangannya, Islam

${ }^{16}$ Hasja Bachtiar, The Religion of Java : Sebuah Penjelasan, Dalam Majalah Ilmu Sastra Indonesia V, (1973), 80-90

${ }^{17}$ Bambang, Memahami Islam Jawa .., 10-11

Humanistika: Vol. 7 No. 22021. 


\section{Miftakhur Ridlo}

di Indonesia tidak pernah terputus dengan Mekah, Madinah dan belakangan Kairo. Adanya jaringan ulama antara Hadramain dengan dunia Melayu Indonesia membuktikan hubungan Islam di Indonesia di tempat lain tidak terputus. ${ }^{18}$

Zamakhsyari Dhofier menyatakan bahwa, apa yang diungkapkan oleh Geertz itu adalah dalam konteks peribahasa Islam di Kraton Jawa pada masa penjajahan terlepas sama sekali dari sumbernya. Yaitu tanpa memiliki lembaga pendidikan yang oleh Geertz sendiri diakui sebagai syarat bagi pengembangannya. Dia tidak menyebutkan tentang Islam dalam lingkup pesantren. ${ }^{19}$

Berita republika pada tanggal 10 Oktober 2002 di halaman 10 berjudul "PPIM (Pusat Pengkajian Islam dari Masyarakat) meruntuhkan Tesis Geertz soal dikotomi santri-abangan" mengabarkan hasil penelitian dari UIN Jakarta di 15 Provinsi : membuktikan varian abangan. santri, priyayi tidak tampak lagi di masyarakat. Latar belakang seseorang tidak menentukan sikap keberislamannya. Seseorang yang punya latar belakang keluarga abangan atau priyayi, ternyata kini menunjukkan sikap semakin santri. ${ }^{20}$

Muhaimin menegaskan bahwa Geertz melakukan kesalahan sejak awal dalam memandang situasi aslinya, salah memahami saat melangkah dan salah menafsirkan pada akhirnya. Secara tidak kritis ia hanya mengambil sumber pada para modernis ketika memulai penelitiannya. Ia membahas santri tapi, jikapun ada, tidak banyak hal yang mencerminkan tradisi santri. Sehingga sebagian terjadi distorsi atas yang sebenarnya terjadi

\footnotetext{
${ }^{18}$ Ibid ..,

${ }^{19}$ Zamakhsyari Dhofier, Tradisi Pesantren : Studi Tentang Pandangan Hidup Kyai, (Jakarta : LP3ES, 1984), 6

20 Abdul Munir Mulkham, Moral Politik Santri, Agama dan Pembelaan Kaum Tertindas, (Jakarta : Erlangga, 2003), 2-3
}

Humanistika: Vol. 7 No. 22021. 
malah selain hanya sedikit mengulas tentang adat Jawa, Geertz tidak banyak mengungkap tradisi agamis orang Jawa. ${ }^{21}$

Nur Syam dalam penelitiannya tentang masyarakat di Tuban Jawa Timur, mengkritik konsep sinkretisme Geertz yang dianggap menggabaikan adanya dialog antara Islam dan budaya Lokal. Studi yang dilakukan oleh Nur Syam, menghasilkan sebuah konsep baru yang disebut Islam Kolaboratif, yaitu realitas keberagaman yang mengadopsi unsur lokal yang tidak bertentangan dengan Islam dan menguatkan ajaran Islam melalui proses transformasi secara terus menerus. Tradisi Islam lokal pada hakikatnya adalah hasil kontruksi diantara berbagai penggolongan sosio relegius yang memang ada dna bergerak dinamis seirama dengan perubahan - perubahan sosial yang terus terjadi. ${ }^{22}$

Saiful Mujab, istilah abangan oleh Geertz dan Ricklefs sudah tidak relevan, berdasarkan fenomena para peziarah dan pengunjung makam imogiri bahwa banyak santri, priyayi dan non muslim juga memparatekkan ritual dan upacara abangan. Fenomena menolak definisi Geertz yang mengeklaim bahwa abangan hanyalah kelompok petani dan masyarakat desa. Point ini sekaligus membantah pernyataan Ricklefs yang menyatakan bahwa abangan adalah kelompok muslim yang tidak menerapkan ajaran ajaran Islam. Ditambah lagi pengelompokan antara santri, abangan dan priyayi saat ini bersifat lebij relative. Beberapa ritual dan upacara di makam Imogiri sebagian besar berhubungan dengan semua kategori yang masuk dalam istilah abangan yang sampai saat ini masik eksis. Pandangan hidup Jawa abangan dalam praktek ritual dan upacara di makam Imogiri

${ }^{21}$ Muhaimin, Islam Dalam Bingkai Budaya Lokal : Potret Dari Cirebon, (Ciputat : Logos Wacana Ilmu, 2001),33

${ }^{22}$ Nur Syam, Tradisi Islam Lokal Pesisiran : Studi Kontuksi Sosial Upacara Pada Masyarakat Pesisir Palang Tuban Jawa Timur, (Disertasi : Universitas Airlangga, Surabaya, 2002)

Humanistika: Vol. 7 No. 22021. 


\section{Miftakhur Ridlo}

merupakan bentuk usaha untuk melestarikan dan mempertahankan hubungan antara manusia dan bukan manusia. ${ }^{23}$

\section{Kajian Perbandingan}

Menurut Woodward, Geertz dipengaruhi oleh mazhab Islam yang beraliran syari'ah modernis, hanya mengidentifikasi Islam dengan mazhab modern, serta menganggap segala tradisi lokal sebagai sesuatu yang asli atau berlatar belakang Hindu-Budha. Apa saja yang dinyatakan syirik oleh informan modernis, juga dianggap keluar dari Islam oleh Geertz. Selanjutnya, Woodward melakukan penelitian mengenai hubungan antara keshalihan Islam normatif dan kebatinan dalam kepercayaan keraton Yogyakarta, serta antara kepercayaan keraton dan agama rakyat. Kajian ini menghasilkan suatu tesis bahwa Islam dan budaya lokal itu adalah sesuatu yang bersifat akulturatif sesuai dengan prosesnya masing-masing. Sehingga antara Islam dan budaya lokal (Jawa) bukanlah suatu yang antonim, tetapi bersifat kompatibel. ${ }^{24}$

Alifuddin menyimpulkan relasi Islam dengan budaya lokal dalam masyarakat Buton berjalan dengan dinamis dan saling mempengaruhi dalam kedua elemen tersebut. Interaksi tu diawali proses pembentukan tradisi Islam melalui konversi kekuasaan lokal. Tradisi Islam berkembang pada abad ke-19 ditandai dengan formalisasi Islam sebagai dasar ideologi Negara. Hal ini dibuktikan dengan diundangkannya Murtabah Tujub sebagai konstitusi resmi kesultanan Buton. Pada akhirnya Islam yang dahulu

${ }^{23}$ Saiful Mujab, Javanese Abangan WOorld Viewand Practices in Imogiri Cemetery Yogyakarta, Jurnal Asketik Vol. 2, No. 1, Juli 2018, 13 - 37

${ }^{24}$ Mark R. Woodward, Islam Jawa Kesalehan Normatif Versus Kebatinan, terj. Hairus Salim HS (Yogyakarta: LKiS bekerja sama dengan The Asia Foundation, 1999), dalam Tulisan Dr. Biyanto M.Ag, hal 33

Humanistika: Vol. 7 No. 22021. 
berpusat di keraton (elit) beralih ke masyarakat umum setelah bergabungnya Buton ke dalam NKRI. ${ }^{25}$

Studi tentang masyarakat sasak Bayan di Lombok terfokus pada konflik ideologis antara dua kelompok kultural religious : Watu Telu dan Watu Lima. ${ }^{26}$ Beralihnya orang sasak dari Boda menjadi Islam, kemudian dari muslim sinkretik dan nominal, disebut $W$ atu Telu menjadi orang Islam yang sempurna. Watu lima memperlihatkan dinamisme kultural dalam cara Islam disebarkan, kemudian diserap, diakomodasi dan diekspresikan di Indonesia. Dinamisme kultural juga melatari fakta bahwa aktivitas penyebaran dan penanaman ajaran Islam merupakan proses panjang dan berkesimbungan dalam antagonism dan asimilasi tiada kesudahan. ${ }^{27}$

Bambang Pranowo, mengetengahkan kelemahan skema santri, abangan yang dikemukakan oleh Geertz dalam memahami kehidupan keagamaan muslim Jawa. Penggunaan dikotomi santri abangan untuk memahami hubungan Islam dan Negara akan menyebabkan terjadinya penyederhanaan yang berlebihan. Ada beberapa pelajaran yang dapat dipetik dari studi di desa Tegalroso, tempat penelitiannya: dari perpektif keagamaan, warga tidak pernah menghakimi keberagamaan seseorang dalam putusan final. Islam di desa Tegalroso sangat dipengaruhi oleh praktik sufistik yang dikembangkan di pesantren Tegalrejo. Pesantren ini

${ }^{25}$ Alifudin, Islam Buton : Interaksi Islam Dengan Budaya Lokal, (Jakarta : Depag, 2007), 395

${ }^{26}$ Watu Telu menunjuk pada orang yang belum menerima ajaran Islam secara utuh, dengan tidak sepenuhnya melakukan perbuatan yang dianjurkan dan diwajibkan Islam. Sebaliknya Watu Lima dipandang orang yang melaksanakan kewajiban agama Islam dengan sempurna (Informan dari Watu Lima). Watu Telu sebuah sistem agama juga dimasnifestasikan dalam kepercayaan bahwa semua makhluk harus meewati tiga tahap rangkaian siklus : dilahirkan, hidup dan mati.

${ }^{27}$ Erni Budiwanti, Islam Sasak : Wetu Telu Versus Watu Lima, (Yogyakarta : LKiS, 2000), 342-343

Humanistika: Vol. 7 No. 22021. 


\section{Miftakhur Ridlo}

dikenal sebagai pesantren tasawuf dan sebagai pencetus kegiatan religious dan kultural yang saat ini digabungkan ke dalam tradisi lokal. ${ }^{28}$

Masdar Hilmy, dengan tulisannya : Menuju Identitas Hibrida Agama : Wajah Berubah Islam Jawa, mencoba meninjau kembali diskusi tentang Islam Jawa dari sudut pandang alternatif. Ia berpendapat bahwa pemaparan Islam Jawa pada studi sebelumnya tidak lagi memadai untuk mengakomodasi transformasi Islam Jawa terkini. Identitas Islam Jawa tidak dapat dilihat dari sudut pandang sinkretis maupun normatif semata, karena identitas Islam Jawa telah menjelma menjadi sesuatu yang berbeda dengan masa lalu. Menjadi seorang abangan atau santri di era pascaGeertz, merepresentasikan pembentukan identitas hibrida secara religius. Dalam konteks Geertz, menjadi abangan berarti tidak bisa sekaligus menjadi santri. Pada saat itu, seorang abangan yang murni dan puritan, bukanlah seorang Muslim yang taat, tetapi Muslim nominal. Sebaliknya, menjadi santri harus dilakukan dengan menguraikan semua jenis identitas dalam pengertian kejawen. Islam Jawa berkaitan dengan mentalitas apapun yang Anda suka yang membentuk identitas hibrida di antara Muslim Jawa. $^{29}$

\section{Kajian Penguat}

Tidak dapat dipungkiri bahwa dalam karya yang monumental pun, dalam perjalanannya menuai beberapa kritik dan ketidaksepakatan terhadap pendapat yang disampaikan oleh Clifford Geertz. Akan tetapi tidak sedikit juga yang mengamini atau menjadikan karya ini sebagai rujukan pertama atau wajib ketika membahas tentang Islam di Jawa.

Niels Mulder menyimpulkan bahwa agama yang terdapat di Asia Tenggara adalah agama yang telah mengalami proses pribumisasi

\footnotetext{
${ }^{28}$ Bambang Pranowo, Memahami Islam Jawa .., 363-364

${ }^{29}$ Masdar Hilmy, Menuju Identitas Hibrida Agama ? Wajah Berubah Islam Jawa, Jurnal Islam Indonesia, Volume 12, Nomor 01, Juni 2018, 45

Humanistika: Vol. 7 No. 22021.
} 
(lokalisasi). Agama asinglah yang kemudian menyerap tradisi lokal bukan sebaliknya. Demikian pula keberadaan Islam dalam kaitannya dengan budaya lokal, yaitu Islamlah yang menyerap budaya lokal. Oleh karena itu, dalam proses interaksi yang terjadi antara agama yang datang dengan kultur lokal, maka agama yang datang niscaya untuk menemukan lahannya dalam kultur lokal. Unsur asing tersebut kemudian disandarkan, sebagai prasyarat untuk dapat bertahan. ${ }^{30}$

Koentjaraningrat menyebut religiusitas Islam Abangan dengan istilah Agami Jawi dan Islam Santri dengan Agama Islam Santri. Kategori ini nampaknya untuk membedakan dua varian religius dan bukan varian sosial seperti santri, priyayi, dan abangan. Yang dimaksudkan Koentjaraningrat dengan Agami Jawi adalah suatu kompleks keyakinan dan konsep-konsep Hindu-Budha yang cenderung ke arah mistik, yang tercampur menjadi satu dan diakui sebagai agama Islam. Sementara itu, Agama Islam Santri lebih dekat pada dogma-dogma Islam baku. ${ }^{31}$

Agama Jawa tidaklah sama dengan agama Islam di Jawa. Penganutnya seringkali mengadakan perbedaan yang tegas antara diri mereka sendiri sebagai penganut agama Jawa dan sebagai pemeluk agama Islam yang mereka sebut wong selam atau muslim. Agama Jawa dimanifestasikan sebagai pemujaan nenek moyang, leluhur yang terdekat, atau pencipta alam semesta, dianggap sebagai sumber kekuatan hidup. Agama Jawa jarang dimanifestasikan dalam bentuknya yang murni. Ilmu kejawen atau ilmu orang Jawa yang oleh Geertz dilukiskan sebagai satu komponen dari mistik priyayi. ${ }^{32}$

${ }^{30}$ Alifudin .., 15-16

${ }^{31}$ Koentjaraningrat, Kebudayaan Jawa, ( Jakarta : Balai Pustaka, 1984 ), 312

${ }^{32}$ Harsja Bachtiar, "The Religion of Java: Sebuah Komentar," dalam Cliffort Geertz, Abangan, Santri, Priyayi dalam Masyarakat Jawa, terj. Aswab Mahasin (Jakarta: Pustaka Jaya, 1989), 521-550

Humanistika: Vol. 7 No. 22021. 


\section{Miftakhur Ridlo}

Agami Jawi seperti yang disinyalir Koentjaraningrat sering disebut dengan Islam sinkretis. Yang dimaksud sinkretis secara umum adalah proses ataupun hasil dari pengolahan, penyatuan, pengkombinasian dan penyelarasan dua atau lebih sistem prinsip yang berlainan atau berlawanan sedemikian rupa, sehingga terbentuk suatu sistem prinsip baru, yang berbeda dengan sistem-sistem prinsip sebelumnya. ${ }^{33}$

Dengan kata lain, sikap sinkretis ${ }^{34}$ adalah suatu sikap atau pandangan yang tidak mempersoalkan benar salahnya sesuatu agama. Yakni suatu sikap yang tidak mempersoalkan murni atau tidak murninya suatu agama. Bagi orang yang berpaham sinkretis, semua agama dipandang baik dan benar. Penganut paham sinkretisme, suka memadukan unsurunsur dari berbagai agama, yang pada dasarnya berbeda atau bahkan berlawanan. 35 Contoh dari sinkrertisme ini dengan : "Strategi untuk membaurkan unsur Islam dalam budaya Jawa dimulai dengan mengganti perhitungan tahun Saka yang berdasarkan perjalanan matahari, menjadi perhitungan tahun Jawa yang berdasarkan perjalanan bulan, dan disesuaikan dengan perhitungan tahun Hijriyah. Mingguan Hijriyah yang terdiri dari tujuh hari, diintegrasikan dengan mingguan Jawa yang terdiri dari lima harian, (Senen Wage, Selasa Kliwon, dan seterusnya). Demikian bulan Jawa disesuaikan dengan bulan Hijriyah, Sura, Mulud dan seterusnya" 36

${ }^{33}$ Heddy Shri Ahimsa Putra, Islam Jawa dan Jawa Islam: Sinkretisasi Agama di Jawa, (Makalah Seminar, Balai Kajian Sejarah dan Nilai Tradisional Yogyakarta \& Kantor Depdiknas DIY, 1995), 2

${ }^{34}$ Sinkretisme berasal dari dari perkataan syin dan kretiozein atau kerannynai, yang berarti mencampurkan elemen yang bertentangan. Darori amin (editor), Islam dan Kebudayaan Jawa, (Yogyakarta : Gama Media, 2000), 87

${ }^{35}$ Simuh, Mistik Islam Kejawen Raden Ngabehi Ranggawarsita, (Jakarta : UI Press, 1988), 2

${ }^{36}$ Simuh, Keunikan Interaksi Islam dan Budaya Jawa : Dalam Seminar Pengaruh Islam Terhadap Budaya Jawa, (31 Nopember 2000), 1

Humanistika: Vol. 7 No. 22021. 
Sinkretime terlihat sangat jelas dalam kehidupan beragama di Jawa. Ini mungkin akibat dari sikap lentur orang Jawa terhadapa agama dari luar. Meskipun kepercayaan animisme sudah mengakar sejak dahulu kala, orang Jawa berturut-turut menerima agama Hindu, Budha, Islam dan Kristen. Dapat dilihat misalnya, betapa pemujaan roh halus masih ada di tingkat terdalam psikologis masyarakat Jawa. Dikalangan mereka, dikenal ungkapan "sedaya agami sami kemawon". ${ }^{37}$

Masalah sinkretisme Islam di Indonesia, terutama di Jawa memang cukup banyak disoroti. Snouck Hurgronje menyatakan, bahwa orang Islam di kawasan ini sebenarnya hanya nampaknya saja memeluk Islam dan hanya di permukaan kehidupan mereka ditutupi oleh agama ini. Ibarat selimut kain yang penuh dengan lobang besar, sehingga didalamanya nampak keasliannya. Bahkan sampai akhir abad ke-20, mayoritas masyarakat Jawa adalah abangan, yaitu hidupnya tidak sesuai tuntunan formal agama. ${ }^{38}$

Nampaknya keyakinan roh dalam tradisi animisme-dinamisme sangat kuat mewarnai pada Agami Jawi dalam memaknai peristiwaperistiwa eskatologis. Simuh membedakan dua jenis pandangan tentang Ruh, yaitu ajaran ruh aktif dan ruh pasif. ${ }^{39}$ Prinsip ruh aktif menurut kepercayaan animisme adalah bahwa ruh orang yang mati tetap hidup dan bahkan menjadi sakti seperti dewa, bisa mencelakakan atau mensejahterakan manusia. Dunia ini dihuni oleh berbagai macam ruh gaib yang bisa membantu dan mengganggu kehidupan manusia. Seluruh ritus dan meditasi religi animisme-dinamisme dimaksudkan untuk berhubungan dengan dan mempengaruhi ruh dan kekuatan gaib tersebut di atas. ${ }^{40}$

\footnotetext{
${ }^{37}$ Muhaimin .., 1

${ }^{38}$ Masyhudi, Berkala Arkeologi xxvii edisi no. 1 / Mei 2007, 51

${ }^{39}$ Simuh, Islam dan Pergumulan Budaya Jawa, (Bandung : Mizan, 2003), 41

${ }^{40}$ Ibid .., 42
}

Humanistika: Vol. 7 No. 22021. 


\section{Miftakhur Ridlo}

Orang Jawa yang memeluk agama Islam, terdapat beberapa ragam dalam pengalaman ajaran Islam. Santri adalah para orang muslim saleh yang menjalankan syariat dengan sunguh-sungguh dan dengan teliti menjalankan perintah agama Islam sebagaimana yang diketahuinya, sambil berusaha membersihkan akidahnya dari syirik yang terdapat di daerahnya. Abangan secara harfiah berarti "yang merah", yang tidak seberapa mengindahkan ajaran Islam dan kurang teliti dalam memenuhi kewajiban agama, sementara cara hidupnya lebih dipengaruhi oleh tradisi Jawa praIslam. Tradisi tersebut menekankan kepada integrasi unsur islam, BudhaHindu dan kepercayaan asli sebagai satu sinkretisme Jawa yang mendasar dan yang sering dinamakan Agama Jawa. ${ }^{41}$

\section{Kesimpulan}

Geertz telah memberikan banyak sumbangsih terkait dengan tipologi masyarakat Jawa, khususnya dalam masalah tipologi keberagamaan. Sejalan dengan itu, banyak kontrovesi dan kritik yang dialamatkan kepadanya. Hal ini dikarenakan adanya ketimpangan gagasan yang disampaikan, terutama globalisasi atau universalitas konsep keagamaan dalam masyarakat Jawa yang terwakili hanya satu, di desa Mojokuto. Sehingga banyak melahirkan penelitian baru yang pembahasannnya nyaris sama, yaitu persinggungan antara Islam dan budaya lokal di wilayah lain seperti : Yogyakarta, Buton, Lombok dan lainlain.

Memang menarik ketika membahas tentang konsep sinkretisme, akulturasi, islamisasi,dan pribumisasi. Hal ini disebabkan keunikan bentuk pertemuan atau proses keislaman di berbagai daerah yang relatife berbeda. Penyebabnya adalah kearifan lokal yang berbeda dan tradisi yang sudah mengakar di kalangan masyarakat. Perbedaan kearifan lokal tersebut

${ }^{41}$ Zaini Muchtarom, Santri dan Abangan Di Jawa, (Jakarta : INIS, 1988), 5 Humanistika: Vol. 7 No. 22021. 
kiranya menjadi motivasi bagi para ilmuwan Islam, untuk lebih menggali beberapa keunikan tradisi yang mungkin belum dimunculkan di kalangan akademisi.

Dalam kurun waktu kekinian, beberapa kajian tentang budaya lokal ataupun pembahasan sekitar tradisi memang sangat genjar dilakukan. Penyebab paling besar adalah banyaknya pihak yang ingin menghilangkan identitas budaya masyarakat setempat. Hal ini dilakukan dengan mengalihkan proses berfikir (paradigma) masyarakat dengan konsep dari luar seperti : hedonisme, pragmatisme dan lain sebagainya. Sehingga menyebabkan masyarakat dan kaum muda seakan-akan kehilangan jati diri bangsa yang sudah berjalan dan dilestarikan sekian lama. Tradisi atau budaya memang harus dikembangkan sedemikian rupa dengan kemodernan yang muncul kekinian, agar dapat difahami dan menyesuaikan dengan proses perkembangan waktu dan pengetahuan yang ada.

Humanistika: Vol. 7 No. 22021. 


\section{Miftakhur Ridlo}

\section{Daftar Pustaka}

Alifudin, Islam Buton : Interaksi Islam dengan Budaya Lokal, (Jakarta : Depag, 2007)

Amin Darori (editor), Islam dan Kebudayaan Jawa, (Yogyakarta : Gama Media, 2000)

Budiwanti Erni, Islam Sasak : Wetu Telu Versus Watu Lima, Yogyakarta : LKiS, 2000)

Bachtiar Harsja, "The Religion of Java: Sebuah Komentar," dalam Cliffort Geertr, Abangan, Santri, Priyayi dalam Masyarakat Jawa, terj. Aswab Mahasin (Jakarta: Pustaka Jaya, 1989)

, The Religion of Java : Sebuah Penjelasan, Dalam Majalah Ilmu Sastra Indonesia $V$, (1973)

Berg Van Den, Hadramaut dan Koloni Arab Di Nusantara, (Jakarta : INIS, 1989)

Dhofier Zamakhsyari, Tradisi Pesantren : Studi Tentang Pandangan Hidup Kyai, (Jakarta : LP3ES, 1984)

El Ashiy Abdurrahman, Makrifat Jawa untuk semua, Jakarta : Serambi, 2011)

Geertz Cliffort, The Religion of Java, (Glencoe London : The Free Press, 1960

- Abangan, Santri, Priyayi dalam Masyarakat Jawa (Jakarta: Dunia Pustaka Jaya, 1981)

Hilmy, Masdar Menuju Identitas Hibrida Agama? Wajab Berubah Islam Jawa, Jurnal Islam Indonesia, Volume Volume 12, Nomor 01, Juni 2018

Koentjaraningrat, Kebudayaan Jawa, ( Jakarta : Balai Pustaka, 1984 )

Islam, M. H. (2019). Aplikasi dan Diferensiasi Pendidikan Islam. HUMANISTIKA: Jurnal Keislaman, 5(1), 73-95.

Humanistika: Vol. 7 No. 22021. 
Tafsir Komprehensif Karya Clifford Geertz:

Abangan, Santri, dan Priyayi Dalam Masyarakat Jawa

Islam, M. H. (2019). ISLAM AND CIVILIZATION (ANALYSIS STUDY ON THE HISTORY OF CIVILIZATION IN ISLAM). Al-Insyiroh: Jurnal Studi Keislaman, 5(1), 22-39.

Islam, M. H. (2019, November). Model Pendekatan Halaqotul MuAllimin Al-Islamiyah dalam Membentuk Kepribadian Yang Rahmatan Lil Alamin Sebagai Identitas Kebangsaan di Pondok Pesantren Al-Mashduqiah. In Proceedings of Annual Conference for Muslim Scholars (Vol. 3, No. 1, pp. 491-503).

Islam, M. H. (2020). TOLERANCE LIMITATION IN FACING RELIGIOUS DIVERSITY BASED ON THE TEACHING OF ISLAM. Nazhruna: Jurnal Pendidikan Islam, 3(1), 1-13.

Islam, M. H., \& Aziz, A. (2020). Transformation of Pesantren in Maintaining Good Character. HUMANISTIKA: Jurnal Keislaman, 6(1), 35-48.

Islam, M. H., \& Maskuri, M. (2020). Pembentukan Kepribadian Multikultural melalui Pendidikan Diversitas. Pendidikan Multikultural, 4(1), 23-44.

Masyhudi, Berkala Arkeologi xxvii edisi no. 1 / Mei 2007

Muhaimin, Islam Dalam Bingkai Budaya Lokal : Potret Dari Cirebon, (Ciputat : Logos Wacana Ilmu, 2001)

Mulkham Abdul Munir, Islam Sejati : Kiai Dablan dan Petani Muhammadiyah, (Jakarta : Serambi, 2003)

, Moral Politik Santri, Agama dan Pembelaan Kaum Tertindas, (Jakarta : Erlangga, 2003)

Muchtarom Zaini, Santri dan Abangan Di Jawa, (Jakarta : INIS, 1988)

Pranowo Bambang, Memahami Islam Jawa, terj : Ridwan Muzir, Jakarta : Pustaka Alvabet dan LaKIP, 2011)

, Islam Faktual : Antara Tradisi dan Relasi Kuasa, (Yogyakarta : Adicita Karya Nusa, 1998)

Humanistika: Vol. 7 No. 22021. 


\section{Miftakhur Ridlo}

Pijper, Beberapa Studi Tentang Sejarah Islam Di Indonesia 1900-1950, terj : Tudjimah dan Yessy Augudin, (Jakarta : UI Press, 1985)

Putra Heddy Shri Ahimsa, Islam Jawa dan Jawa Islam: Sinkretisasi Agama di Jawa, Makalah Seminar, Balai Kajian Sejarah dan Nilai Tradisional Yogyakarta \& Kantor Depdiknas DIY, 1995)

Simuh, Mistik Islam Kejawen Raden Ngabehi Ranggawarsita, (Jakarta : UI Press, 1988)

, Islam dan Pergumulan Budaya Jawa, (Bandung : Mizan, 2003)

- Keunikan Interaksi Islam dan Budaya Jawa : Dalam Seminar Pengarub

Islam Terhadap Budaya Jawa, (31 Nopember 2000)

Suparlan Parsudi, "Kata Pengantar," dalam Cliffort Geertz, Abangan, Santri, Priyayi dalam Masyarakat Jawa, terj. Aswab Mahasin (Jakarta: Pustaka Jaya, 1989)

Syam Nur, Tradisi Islam Lokal Pesisiran : Studi Kontuksi Sosial Upacara Pada Masyarakat Pesisir Palang Tuban Jawa Timur, (Disertasi : Universitas Airlangga, Surabaya, 2002)

Woodward Mark, Islam Jawa Kesalehan Normatif Versus Kebatinan, terj. Hairus Salim HS (Yogyakarta: LKiS bekerja sama dengan The Asia Foundation, 1999)

Zaini Wahid, Dunia Pemikiran Kaum Santri, (Yogyakarta : LKPSM NU, 1995)

Humanistika: Vol. 7 No. 22021. 